\title{
針および線対金網電極系のコロナ放電特性 に及ぼす金網目開きの効果
}

$\begin{array}{llllll}\text { 正員 高 城 } & & \text { 実 } & \text { (西日本工大) } \\ \text { 正員 大久保 } & \text { 利 一 } & \text { (大 分 大) } \\ \text { 正員 川 } & \text { 崎 } & \text { 元 } & \text { 之 } & \text { (西日本工大) } \\ \text { 正員 } & \text { 足 } & \text { 立 } & \text { 宜 } & \text { 良 } & \text { (大 分 大) }\end{array}$

\section{1. まえがき}

電気集じん装置(ESPと略記) の運軽温度を上げる と高抵抗ダストの抵莯率が減少するため, 集じん作用 にとって有害な逆電離の発生が防止できる。この高温 ESP(1) と呼ばれる集じん装置の集じん電極には，熱膨 張によるひすみを考虑して，金網電極が使用される場 合がある(2)。また，実験装圆の必要性からら金網電極が 用いられている。例㫕ば，コロナ放電関連した実験 として平等電界中に篻極性イオンを供給してイオン流 場至形成し(3)，その中で，エアロゾル粒子の実験的観

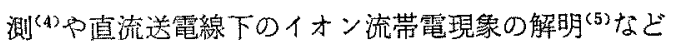
が举り゙られる。更に，計测の必要性加ら平板電極の代 わりに金絧電極が使用されている例としてコロナ放電 によって発生したイオンの移動度の测定(6)(7)やイオン 風速の测定(8) -(10)などがある。しかし，ての場合には 金網自開きをどの程度にすれば平板電極とコロナ電流 の観点から等価的に取报えるかについて系統的に調心 られた詳䍃な基礎データは見あたらない。

天とで，本諭文では金綃目開きが負コロナ放電特性 に及ぼす影整を ESP で使用される平均電界強度 ${ }^{(1)} の$

Effects of Mesh Size on Corona Discharge Characteristics in Needle or Wire to Wire-Netting Electrode System. By Minoru Takajyo, Member (Department of Electrical Engineering, Nishinippon Institute of Technology), Toshikazu Ohkubo, Member (Department of Electrical Engineering, Faculty of Engineering, Oita University), Motoyuki Kawasaki, Member (Department of Electrical Engineering, Nishinippon Institute of Technology) \& Takayoshi Adachi, Member (Department of Electrical Engineering, Faculty of Engineering, Oita University),

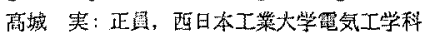

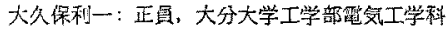

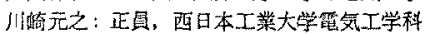

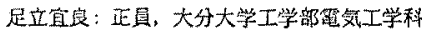

コロナ放電領域を劣慮して，4〜 $6 \mathrm{kV} / \mathrm{cm}$ 程度の常態 空気負荷の場合について実嗝的に調へた。電極モデル として，針対金繹電極系ならびに線対金網極系につい

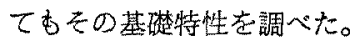

針対金網電極系では，金網電極に流れるコロナ電流 が針対平板電極の場合上ほぼ同じになる鉿網目開きを 明らかにした。また，金網を通り枝りるイオンの透過 度に及ぼす金絧目開きおよび電極の配置条件の影響を 検討するため，金絧電極の下に平视電極を設けた。更 に，目開きが非常に大きくなった場合の，金網加らの 正コロナ放電の開始条件についても調べた。一方，線 対金網電極系では接地した金網電極之平板電極の中間 に線電檄を配置した。この严板形 ESP の電極構成に おいて，金網目開きを変えて接地側における電極のコ ロナ電流を測定した。そのコロナ電流特性の比較加ら 金網のコロナ電流に及ばす金網目開きの影響を定量化 すると共に，平板電極と等洒的なコロナ電流特性をむ つ金網電極の目開きを明ら玑にした。

以上の実験結果から、コロナ放電下で用いる金網の 実効的な電極面積に関する有益な基礎データが得られ ると共に，幾つかの知見が得られたので，その結果を 報告する。

\section{2. 電極系と実験方法}

$\langle 2 \cdot 1\rangle$ 針対金網電極系の概要と実験方法 図 1 亿針対金網形実験装置の概要を示す。針電極は先端削 り角 $30^{\circ}$, 先端曲率半径 $0.3 \mathrm{~mm}$, 針軸径 $6 \mathrm{~mm}$ の黄 銅製である。ESPを考虑して，負極性の直流高電圧 $V$ を $0 \sim 25 \mathrm{kV}$ の筑围で印加した。金網電極 $(70 \times 70$ cm) は目開を $M$ が $1.35 \sim 50 \mathrm{~mm}$ の9種類を使用し 


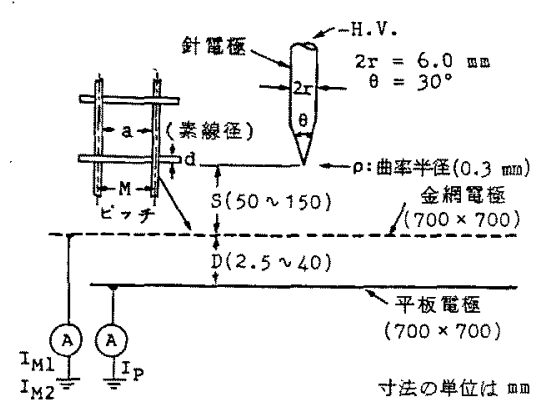

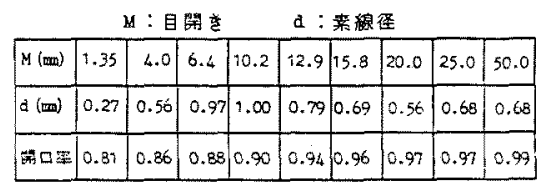

図 1 針一金網形実験装置

Fig. 1. Schematic diagram of a needle to wire-netting electrode system.

た。これらの目開き $M$ 之素線径 $d$ を同図中に示す。 目開き $M$ は図 1 のようにピッチ $M=a+d$ を用いた が，金網の開口率（卖線間距離 $a$ で決まる正方形の 面積／菜線中心間 $M$ で決まる正方形の面皘） も同図 中に示した。針電極と金網電極の間隔 $S$ は $5 \sim 15 \mathrm{~cm}$ の範囲で変化した。

実酠は負コロナ放電特性に及ぼす金網目開きの効果 を調べると共に，金網電極を通り拔けるイオンの透過 度が金網目開きおよび電極の配置条件によって受ける 影響を調べた。乙の場合には，平板電極（アルミ板， $70 \times 70 \mathrm{~cm})$ を金網電極の下㑡に間隔 $D$ だり離し, 電 流計を通して接地した。そして，そのときの金網電極 に流入する電流（以下，金網電流上略記）および平板 電極に流入する電流 (以下，平板電流之略記）をそれ ぞれ測定した。実験はすべて静止大気圧空気中で行っ た。

$\langle 2 \cdot 2\rangle$ 線対金網電極系の概要と実験方法 四 2 に実験装犆の概要走示す。線対金網電極系の真コロナ 放電特性に及ぼす目開きの効果を検討するため, 接地 した金網電極と平板電極の中間に線電極を配置して 平板形 ESP の電極構成とした。このような電極配置 にする上, 平板電流は後述のように金網目開き変化の 影響を無視できるので，線対平板電極系之線対金網電 極采のコロナ放電特性を同時に測定でき，その比較検 討が容易になる。これより，金網目開きを変えた場合 のコロナ放電特性の相違加ら，金網のコロナ電流の大 きさに及ばす目開きの効果を定量化するととができ る。平板電極は $30 \times 50 \mathrm{~cm}$ で, 金網電極は同図中の あのを使用した。線電極（直径 $0.5 \mathrm{~mm}$, 有勃長 30 $\mathrm{cm})$ はステンレス鋼線を使用し，とれに負極性の直流

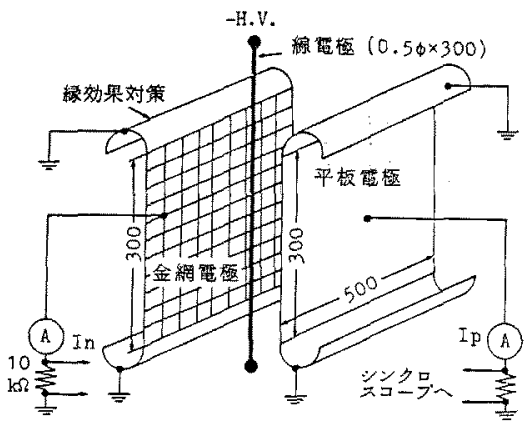

寸法口觜媇位 $\mathrm{mm}$

\begin{tabular}{|c|c|c|c|c|c|c|c|}
\hline$M(m)$ & 3.0 & 5.0 & 7.0 & 10.0 & 14.0 & 20.0 & 28.0 \\
\hline $\mathrm{d}(\mathrm{mm})$ & 0.53 & 0.66 & 0.77 & 0.66 & 0.77 & 0.66 & 0.77 \\
\hline 骕口㚙 & 0.82 & 0.87 & 0.89 & 0.93 & 0.95 & 0.97 & 0.97 \\
\hline
\end{tabular}

図 2 線一金榊形実駼装置

Fig. 2. Schematic diagram of single wire to wire-netting electrode system.

高電圧 $V$ を〜 $50 \mathrm{kV}$ の範团で印加した。

実験は電極間距離 $S$ を $15 \mathrm{~cm} の$ 範囲内で, 金網 の目開きを变えた場合，金網電流 $I_{n}$ および平板電流 $I_{p}$ をれぞれ測定し，両電極におげるコロナ開始電王 およびコロナ放笔特性の相違を検討した。更に，コロ 士放電特性加ら見た金網電極之平板電極の等価性を異 なる角度から検討するため, 片側の平板電極はそのま まで，金網電極だけを線電極側得高 $S$ の $60 \%$ まで 平行移動させた。とのとき，金絧に流れるコロナ電流 が平板に流れるコロナ電流と等しくなる金網電極の移 動距離 $L(\mathrm{~mm})$ を各目開きについて実測し，そのとき の見措けの平均電界強度の变化 $\Delta E_{\mathrm{ave}}$ を調べた。

\section{3. 結果と考察}

\section{〈3.1〉）剑対金網電極系におけるコロナ放電特性}

図 3 は針対金網電極系でのコロナ放電特性を示す。 $S=5 \mathrm{~cm}$ 一定下に扮ける金網電流 $I_{M 1}$ の平方根之 $V$ の関係をそれぞ机の $M$ に対して示した。 $M$ が1.35〜 $20.0 \mathrm{~mm}$ に対する $\sqrt{I_{M 1}}-V$ 特性は $M$ の変化による差 異が見られず，針対平板電極系之同様なコロナ放電特 性を示す。一方, $M>20 \mathrm{~mm}$ 以上の $M$ 亿なると, 四 3 に示されるようにコロナ放電特性に目開きの影響が 現われる。以上より $1.35 \leq M \leq 20 \mathrm{~mm}$ では $M$ の增 大に伴う金網電極の形状の変化に関係なく, 同一印加 電圧に対するコロナ電流值は変わらない。従って, こ の之きの金網電極は，等価的に平板電極と見なせると とを示している。目開きの影響が現われない理由とし て，金網を通り抜けたイオンが回り込むようにして金 


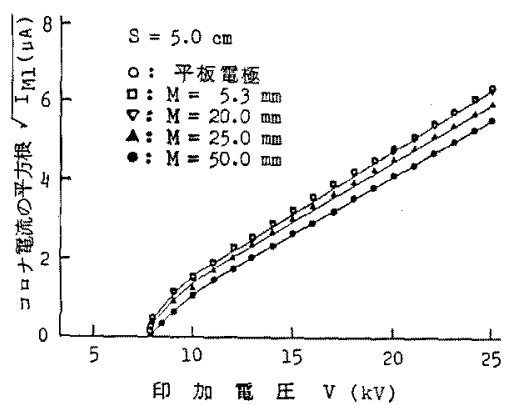

因 3 針対金網拉よび平板電極系における コロナ放電特性

Fig. 3. Corona current-voltage characteristics for a needle to wire-netting electrode and plate electrode.

網に捕捉されているととが考えられる。

$M>20 \mathrm{~mm}$ の目開きでは， $M$ が大きくなるにつれ， 金網電極近傍の電界分布の不均一性が增すようにな り，金網の実効的な電極面皘が減少するため，同一 $V$ に対する $I_{M 1}$ 屯次第に減少する。乙の場合，金網を通 り拔けるイオンむ存在すると考えられるが，針対金網 電極系汇招けるイオン風の举動 ${ }^{(8)}$ 加ら，針電極直下K 多く分布しているものと考えられる。

（1）金網電極を通り抜けるイオン嚜の検討

〈3.1〉節で考察した $M<20 \mathrm{~mm}$ と $M>20 \mathrm{~mm}$ のコ ロナ放電特性の相違を検討するために，金網電極の下 に平板電極を設けて(図 1 参照)，そのときの金網電流 $I_{M 2}$ およよ゙平板電流 $I_{p}$ をそれぞれ測定した。ただし， 平板電極がない場合の金網電流を $I_{M 1}$ としている。 $M$ が $20 \mathrm{~mm}$ 以下で針電極と金網電極の距離 $S$ が一定の場 合，金網電流 $I_{M 1}$ と平板電極を配置したときの金網電

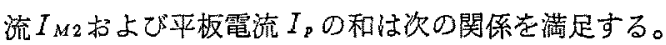

$$
I_{M 1}=I_{M 2}+I_{p}
$$

(1)式より目開きが $20 \mathrm{~mm}$ 以下ではイオンは一度金 網を通り抜けても再び金網に捕捉されることがわか る。とのとき，目開きが大きいほど $I_{M 1}$ に対する $I_{M 2}$ の割合は小さくなる。一方， $M>20 \mathrm{~mm}$ の場合住(1) 式は成立せず，次のような不等式になる。

$$
I_{M 1}<I_{M 2}+I_{p}
$$

(2)式は目開きが $20 \mathrm{~mm}$ より大きくなった場合，金 網を通り抜けて捕捉されずに飛びさっていくイオンが 存在するこよを示唆している。

园 4 は $V=25 \mathrm{kV}$ で，平板と金網の間隔 $D$ が 5 $\mathrm{mm}$ の場合の $\sqrt{I_{p}}-M$ 特性を $S$ をパラメータとし 示した。 $M$ が約 $4 \mathrm{~mm}$ 以上では $V T_{p}$ は $M$ 比例 し，金綱を通り抜りるイオン量は $M$ の增大および $S$ の減少に伴って增加することがわかる。目開き $M$ が

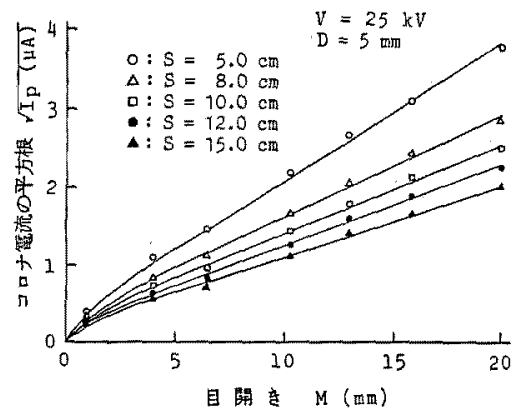

図 $4 \sqrt{T_{p}}-M$ 特性

Fig. 4. Square root of current flowing to the plate electrode as a function of mesh size.

$20 \mathrm{~mm}$ 以下では $I_{M 2}>I_{p}$ となるが，乙れらの電流の 比 $I_{p} / I_{M 2}$ は金網を通り技けるイオン量の目安を与 える。以下では，この割合をイオンの透過度と呼ふて とにする。イオンの透過度は $V, M, S$ および $D$ の変 化によって影響を受けるので，以下によ゙のパラメータ の影製が大きいかその検討を行った。

図 5 (a)はイオンの透過度に及恬す $V$ の影響を示 す。イオンの透過度は $S$ および $D$ が一定の下では， 金網目開き $M$ による影響が大きくなるが， $V$ の変化 による影響はほとんどない。乙の特徵ある傾向は $S$ 之 $D$ 依存しない。

次に, $D=5 \mathrm{~mm}$ の場合のイオンの透過度之目開き $M$ の関係を $S$ をパラメータとして示したのが，図 5 (b)である。ここで重要なことは， $D$ と $M$ が一定で あれば, イオンの透過度に及ばす $S$ 変化の影響は小 さいととがわかる。また，同図には示されていない が, $M=20 \mathrm{~mm}, D=2.5 \mathrm{~mm}$ の場合のイオンの透過 度は約 1.0 となり，それぞれの電極に流㞦るコロナ電 流はほ深等しくなる。

$S=10 \mathrm{~cm}$ 一定で $D$ を変えた場合，イオンの透過 度がどのように変化するか子代表的な $M$ について示 したのが図5(c)である。平板電極を金網電極に近つ けていくと，イオンの透過度が指数関数的に增加する ことから，金綃を通り拔けたイオンの密度は金網の近 傍で高く，金網加離れるに従ってその密度頭著に 隇少していると考えられる。

（3）金網加の正コロナ放電の開始条件 針対 金網電極系において， $M$ が大きく印加電化が高くな ると，金網電極侧加ら正コロナ放電が起とり，コロナ 放電特性上江変化が生じると考えられる。そてで，M が非常に大きくなった場合について，針対線笔傩系に おけるコロナ放電特性を素線径 $d$ の異なる 6 種類の 線電極を用いて調べた。 


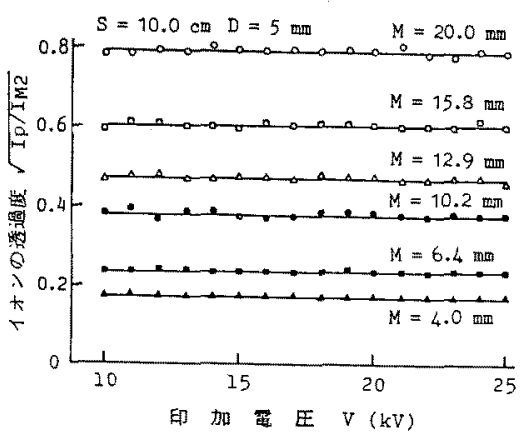

(a) $\sqrt{I p / I M 2}-V$ 珄

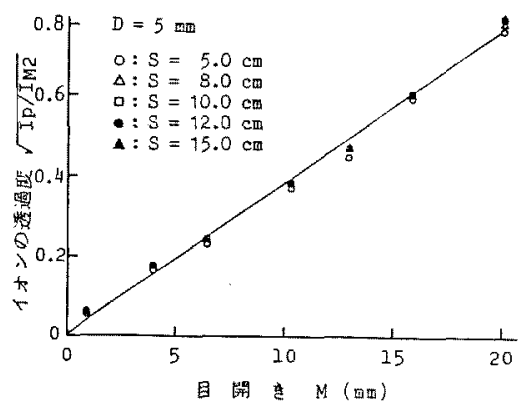

(b) $\sqrt{\operatorname{Ip} / I_{M 2}}-M$ 栍

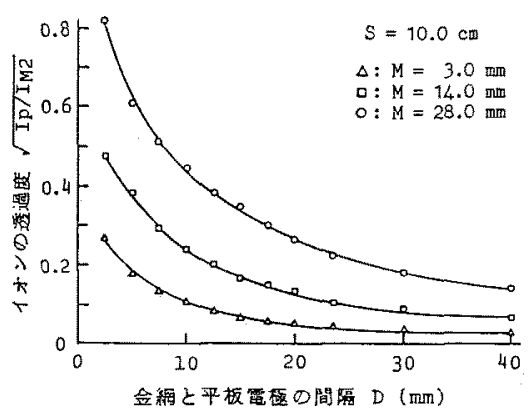

(c) $\sqrt{I p / I M 2}-D$ 特性

図 5 平板電極と金網電極へのコロナ電流に 及ほすす加電圧，目開きおよび 電極間距離の影響

Fig. 5. Ratio of corona currents flowing to plate and wire-netting electrodes as functions of applied voltage, mesh size and space distance.

図 6 は $d=0.45 \mathrm{~mm}$ の場合の線電流 $I_{W}$ の平方根之 $V$ の関係を示した。乙れより，電極間距離 $S$ の大き さに加かわらず特性上に折机点加生じ，正コロナ放電 はこの折れ点付近で線電極から発光することが観測さ れた。更に，因6のような電流急増点は針対球電極系 において李特性上の折れ点付近で球電極側加ら正コ口 ナ放電が起こり，イオン風の吹き返しが生じるととが 報告されている(12)。

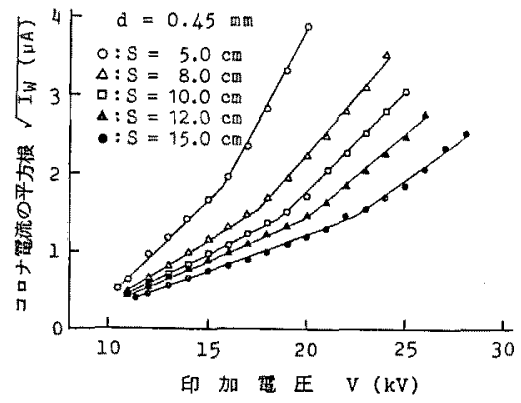

図 6 針対線電極系でのコロナ放電性

Fig. 6. Corona current-voltage characteristics for a needle to single wire electrode.

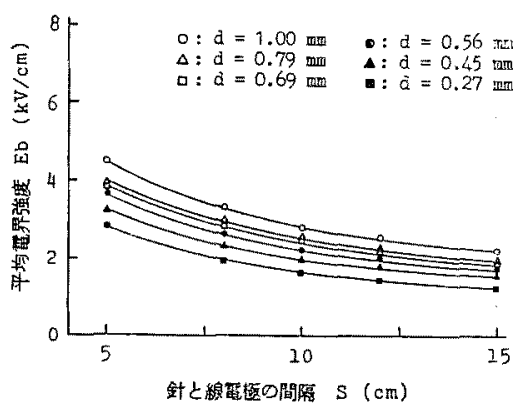

图 7 正コロナ開始平均電界強度 $E_{b}$ 之 $S$ の関係 Fig. 7. Positive corona onset average electric field strength $E_{b}$ as a function of space distance $S$.

そこで，コロナ放電特性上の折れ点を正コロナ放電 D開始平均電界強度 $E_{b}$ (印加電圧 $V /$ 電極間距離 $S$ ) と定義した。図 $7 に E_{b}$ とSの関係を示した。とれよ り，線電極が細くなるほど正コロナ放電が発生しやす くなることが確認できる。Sが大きくなると相対的に 線電極の直径が小さくなるため，放電空間の不平等性 が強末り $E_{b}$ 李低下している。しかしながら，前述の 釬対金網電極系代おいてはこのような現象は晃られな 加った。従って，本実験における印加電压 $25 \mathrm{kV}$ 程 度までは，金網からの正コロナ放電は発生しないと言 える。

\section{〈3・2〉 線対金網電極系におけるコロナ放電特性}

線電極と対称な位㯰に金網電極と平板電極を配置し て平板形 ESP の電極粠成とした。このような配置に すると，既に述べたように線対金網電極と線対平板電 極のコロナ放電特生の相違学同時汇測定できるため， 金網電流に及ぼす目開きの影響が定量的に把握され る。

因8（a)は $M$ が $3 \mathrm{~mm}$ の場合のコロナ放簖特性 で，破線と実線はそれぞれ金網電流 $I_{n}$ 之平板電流 $I_{p}$ を示す。 $M=3 \mathrm{~mm}$ では, 同一条件下のコロナ電流值 


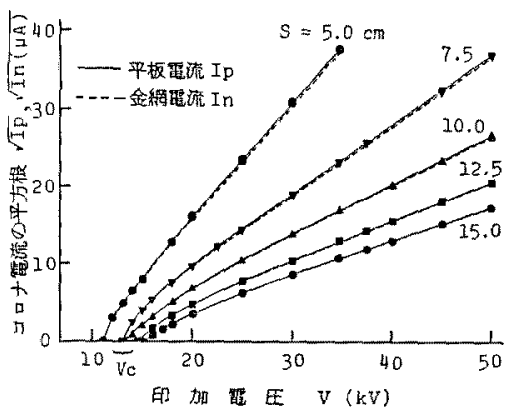

(a) $M=3.0 \mathrm{~mm}$

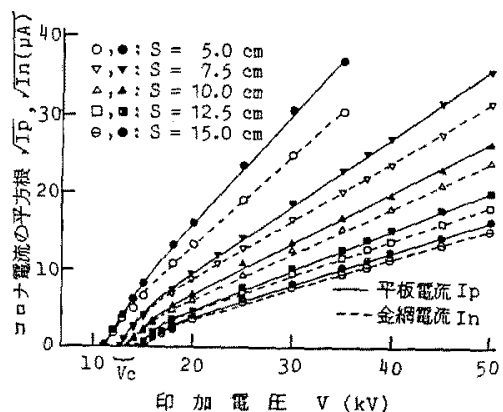

(b) $M=28.0 \mathrm{~mm}$

四8 線対金網抢上び平板電極系における コロナ放笪特性

Fig. 8. Corona current-voltage characteristics for a wire to wire-netting electrode (mesh size $M=3 \mathrm{~mm}$ and $M=28 \mathrm{~mm}$ ) and plate electrode.

の違いは両電極の電流の差が最委大きい $S=5 \mathrm{~cm}$ の 場合であ，約 $1 \%$ の違いしかない。更に，Sが大きく なるにつれて両電極のコロナ放電特性は良く一致する ので，実質的に平板電極と見なせる。また，コロナ開 始電圧 $V_{0}$ あ各 $S$ について両電極とあにほは同じで あった。コロナ放電が旺盛となる可視コロナ領域で は，針対金網電極系の場合と同様にコロナ電流の平方 根と印加電生の関係は直線関係を示す。次化， $M$ 方 $28 \mathrm{~mm}$ の場合におけるコ口ナ放電特性を园 8 (b) に示 す。との場合む，V。は両電極之むに良く一致するが， $I_{p}$ と $I_{n}$ の差は $M=3 \mathrm{~mm}$ の場合に比べて顯著们現 われる。また，線対金絧電極系では $M$ が $20 \mathrm{~mm}$ 以 下の場合で屯，Vが增加するにつれてコロナ電流の差 は增加する。しかむ，乙の倾向洁 $S$ が小さくなる结 ど強くなる。これは，コロナ輝点の発生状態や空間電 荷の密度分布(23)广どが針対金網電極系之法違うため， 金網へのイオンの流入状態执よび金繹を通り抜けるイ オンの量などが異なるむのと考元られる。とれらを解 明するに法，金網電極近傍のイオンの振舞を検討する 必要がある。定性的には， $M$ の增大に伴って金網電極

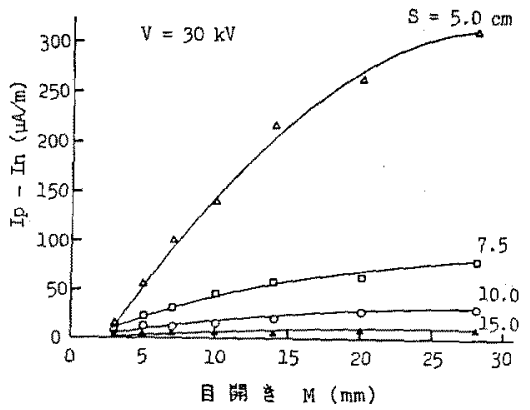

因 9 コロ+電流の差 $I_{p}-I_{n}$ 之目開き $M$ D関係

Fig. 9. Relation between corona current differrence $I_{p}-I_{n}$ and mesh size $M$.

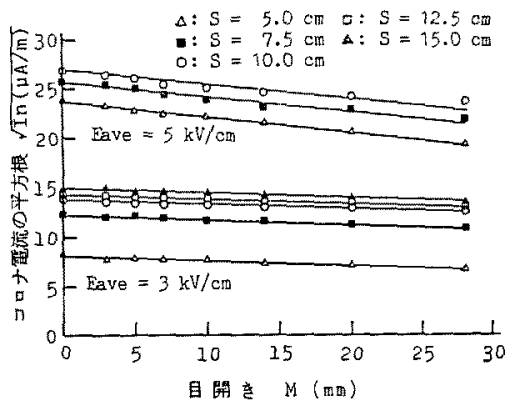

图 10 目開き $M$ が金網電流 $I_{n}$ に及保す影謷

Fig. 10. Effects of mesh size $M$ to wirenetting current $I_{n}$.

近傍の等電位面が波打つと共沉，金網電極の下沉もぐ り込む分布 ${ }^{(3)}$ となる。イオンは電気力線汇沿って移勳 するので，一度金網を通り抜けたイオンの一部は再び 金網に回り込んで捕捉されることは十分考えられる。

図 9 岋 $V=30 \mathrm{kV}$ 一定下に扔りる $I_{p}$ と $I_{n}$ の差之 目開きの関係を示した。Sが小さくなるほど目開きの 勃果が顕著となる。乙れは，S方減少するにつれて相 対的に $M$ が大きくなる結果，実勃的な電極面皘か減 少するたるである。

（1）金網電流に及ぼす目開きの影響，金網の $M$ が金網電流 $I_{n}$ に及济す影響を平均電界強度 $E_{\mathrm{ave}}$ (畞加電E $V /$ 電極間距離 $S$ ) が $3 \mathrm{kV} / \mathrm{cm}$ およよび $5 \mathrm{kV}$ ) $\mathrm{cm}$ の場合について検討した。

因 10 には $I_{n}$ の平方根と $M$ の関係を示した。 $I_{n}$ は $M$ の堌大に伴って直線的低下することがわか る。この場合の $I_{n}$ の減少率は， $E_{\mathrm{ave}}$ の堌加と共に大 きくなるが，Sによる影響は小さい。困中の $I_{n}$ と $M$ の関係を示す実験式は次式で示される。

$$
I_{n}=(A M+B)^{2}
$$

ただし，（3）式を満足する範团は $M \leq 28 \mathrm{~mm}, 5 \leq S$ $\leq 15 \mathrm{~cm}$ である。赛験定数 $A$ は電極系の幾何学的寸 


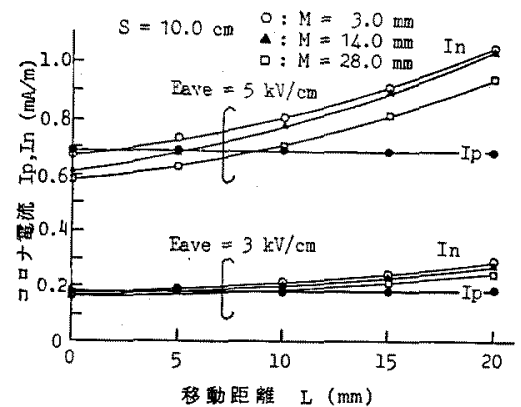

図 11 金網電極を平行移動ささた場合の コロナ踭流特性

Fig. 11. Effect of moved distance of wirenetting electrode towards single wire electrode on corona current characteristics.

法に依存する定数である。 $B$ は平板電流 $I_{p}$ である。 $A$ は $S$ 亿かか力らずほぼ一定值となり， $E_{\text {ave }}$ が $3 \mathrm{kV} /$ $\mathrm{cm}$ では, 目開き $1 \mathrm{~mm}$ あたり $4.96 \times 10^{-2}(\mu \mathrm{A} / \mathrm{m})^{0.5}$ の減少となる。 $E_{\text {ave }}$ が 4 および $5 \mathrm{kV} / \mathrm{cm}$ になると。 $A$ はそれぞれ 1.7 および 2.5 倍大きくなり，金網目 開きの変化によるコロナ電流の減少割合が把握でき る。

（2）コロナ放電特性から見た金網電極と平板電極 の等洒性ココナ電流の観点から見た金網電極之平 板電極の等価性を異なる角度加ら検討するため, 平板 電極のはうは $S$ を一定に保ち，金網電極だけを線電 極倒儿平行移勳して，金網へのコロナ電流が平板電極 へのコロナ電流と等しくなる金網の移動距離 $L(\mathrm{~mm})$ を求的た。

図 11 は $E_{\text {ave }}$ が $3 \mathrm{kV} / \mathrm{cm}$ および $5 \mathrm{kV} / \mathrm{cm}$ 一定の 下で， $S$ が $10 \mathrm{~cm}$ の場合の金網電極の移動化伴う $I_{n}$ の変化と，そのときの $I_{p}$ を $M=3,14$ および $28 \mathrm{~mm}$ について示した。同図中の $I_{n} と I_{p}$ の交点は金網の 実効電極面積が平板電極と見なせる条件を示す。ただ L，金網電極の最初の設定位置 $(S=10 \mathrm{~cm})$ を基準位 置 $(L=0 \mathrm{~mm})$ とした。 $I_{n}$ は次第に大きくなるが， $I_{p}$ は金網の移動には影響されず一定值を保つととがわか る。以上述べた傾向は他のSの条件に対しても全く 同様であった。

図11を基にして $L$ と $M$ の関係を示したのが図 12 である。いずれの $S$ においてあ $L$ は $20 \mathrm{~mm}$ 付近 までは $M$ に比例するが， $M>20 \mathrm{~mm}$ では次第に飽和 する。これは，金網電極近傍での電位变化が大きくな なり，電界が強められるためと考えられる。こてで， $M=3 \mathrm{~mm}$ の場合に注目すると，コロナ放電が比較的 活発な場合でも，2 $\mathrm{mm}$ 以下の平行移動で実質的に平 板電極として取报えることを示している。金網電極の

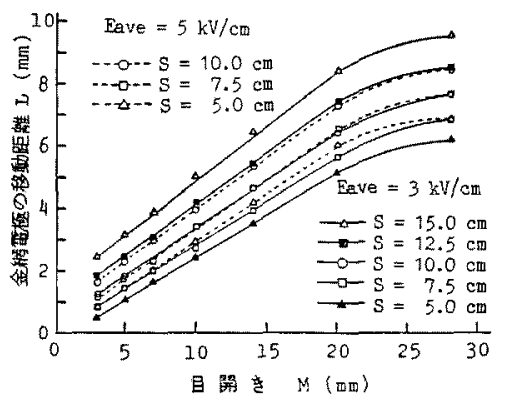

図 12 平板電極とみなせる金網電極の移動距離 Fig. 12. Moved distance of the wire-netting electrode equivalent to plate electrode from the viewpoint of corona current characteristics.

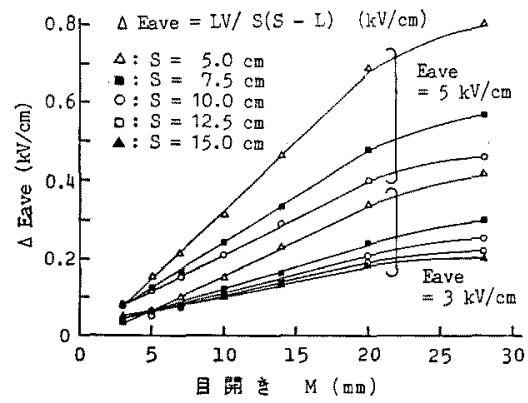

図 $13 \Delta E_{\mathrm{ave}}$ 亡目開き $M$ の関係

Fig. 13. Relation between increase in average electric field strength $\Delta E_{\text {ave }}$ and mesh size $M$.

移動化伴う平均電界強度の增加分 $\Delta E_{\mathrm{ave}}$ は $L V /\{S$ $(S-L)\}$ となる。この $E_{\mathrm{ave}}$ の增加分と $M$ の関係を図 13 亿示した。 $E_{\mathrm{ave}}$ 一定の下では， $S$ が小さくなるに つれ $\Delta E_{\mathrm{ave}}$ は大きくなる。 $M=3 \mathrm{~mm}$ ではほ上んど $S$ 関係なく $0.1 \mathrm{kV} / \mathrm{cm}$ 以下の変化しかか心ととが確 認できた。

\section{4. まとめ}

針対金網電極系および線対金網電極系を用いて，金 網電極の目開きが真コロナ放電特性に及济す影響を常 態空気負荷の場合について調べた。その結果を要約す ると次のようである。

(1)針之金網電極の間隔驾 $5 \sim 15 \mathrm{~cm}$ の針対金網電 極系において金絴目開きが $20 \mathrm{~mm}$ 以下では，コロナ 放電特性に及代す目開きの影響はなく，針刘平板電極 柔之ほぼ同様な特性になる。

(2) 平板電流 $I_{p}$ と金網電流 $I_{M 2}$ の比 $I_{p} / I_{M 2}$ は 金網を通り报けるイオンの透過度を示す日安となる。 この透過度は印加電圧ならびに針と金網電極の間隔の 変化の影響は活とんぞ受けず，金䋧目開きと金網と平 板電極の間隔の变化に対して強く影響を受ける。 
（3）針対線電極において，線電極加ら正コロナ放 電力闗始する平均電界強度は電極間距離の增加に伴っ て低下する。また，素線径が小さくなるほど正コロナ 放電が起こりやすくなる。一方，本実験符团に呫りる 針対金網電極では正コロナ放電は発生しない。

（4）平均電界強度が一定下に拈ける金網電流の平 方根は金網目開きに反比例する。このときの金網電流 の減少率は，平均電界強度の增加に伴って大きくなる が，電極間距離の影響は小さくほぼ一定となる。

（5）電極間距離が $5 \sim 15 \mathrm{~cm}$ の線対金網電極系任 おいて，実質的に平板電極亡見なせる金網目開きは 3 $\mathrm{mm}$ であることがわかった。また，コロナ放電が活発 な領域に打いて，線笔極方向に $2 \mathrm{~mm}$ 以下の平行移動 で平板電極と等価となる。この場合の平均電界強度の 增加分は $0.1 \mathrm{kV} / \mathrm{cm}$ 以下である。

本研究の指針を電気学会放電研究会にて御教示いた だいた名古屋工業大学名誉教授三好保憲氏，日ごるよ り御指導ならごに御支援をいただく九州大学大学院総 合理工学研究科赤崎正則教授，同工学部村上昭年教 授，原 雅則教授ならび汇西日本工業大学元教授 楚本 清隆氏に深く謝意を表します。

(昭和 61 年 2 月 3 日受付, 同 61 年 5 月 29 日再受付)

\section{文献}

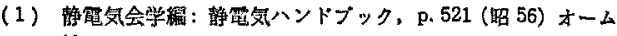
社

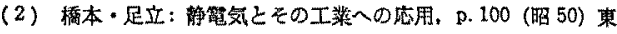
京電機大学出股局

(3) M. Misakian : "Generation and Measurement of D.C. Electric Fields with Space Charge", J. Appl. Phys., 52, 3135 (1981)

(4) R.S. Withers, J.R. Melche \& J.W. Richmsnn : "Charg. ing, Migration and Electrohydrodynamic Transport of Aerosols", J. Electrostatics, 5, 228 (1978)

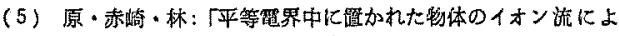

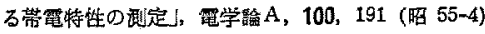

(6) N. Fujioka, Y. Iunoda, A. Sugimura \& K. Arai: "Influence of Humidity on Variation of Ion Mobility", IEEE Trans. Power Apparatus Syst., PAS-102, 911 (1983)

（7）須永：「コロナ放電仙上って発生するイオンの移動度」，霆力 中央研究所技研坏告, No. 178047 (昭 54-6)

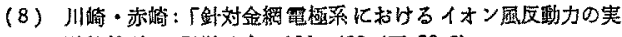
臨的众討」, 電学諭A, 104, 428 (昭 59-8)

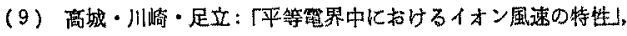

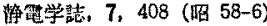

(10) M. Robinson: "Movement of Air in the Electric Wind of the Corona Discharge", Trans. Amer. Inst. Elect. Engrs, 80, 143 (1961)

(11) H.J. White: Industrial Electrostatic Precipitation, p. 235, (1963) Addison-Wesley Pub.

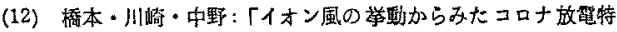
性の考察」, 昭 49 需気学会全大(6)。717

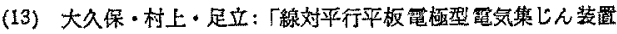

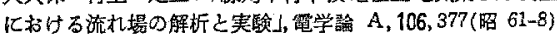

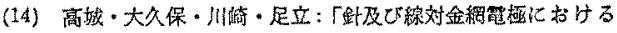

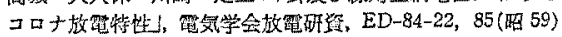

